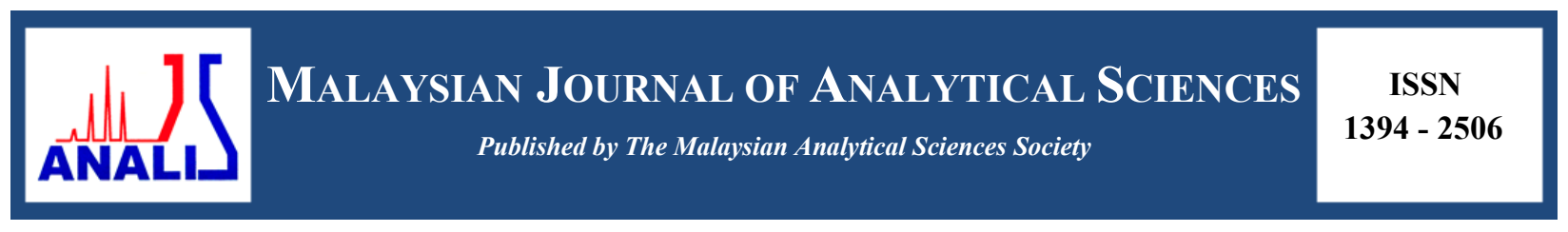

\title{
THE CHEMICAL CONSTITUENTS FROM THE FRUITS OF Johannesteijsmannia altifrons AND ANTIBACTERIAL ACTIVITY
}

\section{(Komposisi Kimia Daripada Buah Johannesteijsmannia altifrons dan Aktiviti Antibakteria)}

\author{
Noor Aziiraa Sabri ${ }^{1}$, Wan Yaacob Wan Ahmad $^{1 *}$, Nur Shafiqa Abdullah ${ }^{1}$, Nazlina Ibrahim $^{2}$ \\ ${ }^{I}$ School of Chemical Sciences and Food Technology, Faculty of Science and Technology \\ ${ }^{2}$ School of Biosciences and Biotechnology,Faculty of Science and Technology \\ Universiti Kebangsaan Malaysia, 43600 UKM Bangi, Selangor, Malaysia \\ *Corresponding author: wanyaa@ukm.edu.my
}

Received: 10 October 2016; Accepted: 16 January 2017

\begin{abstract}
Isolation on the hexane extract of the fruits of Johannesteijsmannia altifrons by vacuum liquid and radial chromatography yielded three known compounds namely $\beta$-sitosterol, $\gamma$-taraxasterol and stigmasterol. Their structures were determined using one-dimensional and two-dimensional nuclear magnetic resonance spectroscopy, fourier transform infra-red spectroscopy and mass spectrometry. All the isolated compounds were tested for their antibacterial activity using disc diffusion and minimum inhibitory concentration (MIC). All three compounds showed weak and moderate activities against all nine tested bacteria. This is the first report on the isolation of compounds from this species and on the antibacterial activity of $\gamma$-taraxasterol.
\end{abstract}

Keywords: Johannesteijsmannia altifrons, $\beta$-sitosterol, $\gamma$-taraxasterol, stigmasterol, antibacterial

Abstrak

Pemencilan ke atas ekstrak heksana bagi buah Johannesteijsmannia altifrons dengan kromatografi cecair vakum dan radial menghasilkan tiga sebatian yang pernah ditemui bernama $\beta$-sitosterol, $\gamma$-taraksasterol dan stigmasterol. Strukturnya ditentukan dengan spektroskopi resonans magnet nukleus satu-dimensi dan dua-dimensi, spektroskopi infra-merah transformasi Fourier dan spektrosmetri jisim. Kesemua sebatian yang dipencilkan diuji aktiviti bakterianya dengan kaedah peresapan cakera dan kepekatan perencatan minimum (KPM). Kesemua tiga sebatian menunjukkan aktiviti yang lemah dan sederhana terhadap kesemua sembilan bakteria yang diuji. Ini merupakan laporan pertama mengenai pemencilan sebatian daripada spesies ini dan mengenai aktiviti antibakteria bagi $\gamma$-taraksasterol.

Kata kunci: Johannesteijsmannia altifrons, $\beta$-sitosterol, $\gamma$-taraksasterol, stigmasterol, antibakteria

\section{Introduction}

Johannesteijsmannia belonging to the Arecaceae family contains four species which are J. altifrons, J. lanceolata, J. magnifica and J. perakensis. Johannesteijsmannia altifrons which is also known as "Daun Sang" (Malay) and Joey Palm (English) commonly found in Kelantan, Perak, Terengganu, Pahang, Johor and Kedah [1]. No chemical constituents have ever been isolated or characterized from Johannesteijsmannia altifrons. The family of Arecaceae has been reported to contain flavonoids [2], alkaloids [3], terpenoids, steroids, fatty acids and tannins [4].Thus, conducting a phytochemical study on Johannesteijsmannia altifrons is vital to further enrich our knowledge on the species. In this study, the hexane extract from fruits of Johannesteijsmannia altifrons was purified and led to the discovery of known $\beta$-sitosterol, $\gamma$-taraxasterol and stigmasterol. Previously, Singh and Ghanapriya [5] reported $\beta$ sitosterol and stigmasterol inhibited at low levels (1+) against Staphylococcus aureus, Bacillus subtilis and 
Escherichia coli. According to previous study by Manriquez et al. [6], both $\beta$ - sitosterol and stigmasterol gives MIC value at $16.5 \mu \mathrm{g} / \mathrm{mL}$ against Staphylococcus aureus. Previous study discovered no inhibition of $\beta$-sitosterol and stigmasterol reported on Escherichia coli, Bacillus subtilis and Salmonella thyphimurium [6]. There are three types of extracts in this study which are hexane, chloroform and methanol but hexane extract was chosen to be purified further. This is because compounds from hexane extract are easily separated and purified compared to the other two extracts.

\section{General}

\section{Materials and Methods}

Different spectroscopic methods were used to elucidate the structures of $\beta$-sitosterol, $\gamma$-taraxasterol and stigmasterol including ultraviolet-visible spectroscopy, mass spectroscopy, fourier transform infra-red spectroscopy, onedimensional, two-dimensional and carbon-13 nuclear magnetic resonance spectroscopy. The one-dimensional, twodimensional and carbon-13 nuclear magnetic resonance spectroscopy spectra were recorded using Avance III 600 MHz Bruker. Deuterated chloroform $\left(\mathrm{CDCl}_{3}\right)$ was used as the NMR solvent with the chemical shifts, $\delta_{\mathrm{H}}$, in ppm and the values of coupling constants, $J$, in Hz. Mass spectra were recorded by using the LC-mass spectrometry (LC-MS) on the Dionex/Bruker Micro ToFQ. The infra-red spectra were recorded on the Perkin-Elmer Spectrum 400 and the UV-VIS spectra were obtained in chloroform using UV-2400PC. Vacuum liquid chromatography (VLC) was prepared by using silica gel of Merck 7747. For radial chromatography $(\mathrm{RC})$, silica gel with $\mathrm{PF}_{254}$ containing gypsum (Merck 7749) was used. Thin layer chromatography (TLC) was performed on commercially pre-coated aluminum silica gel $60 \mathrm{~F}_{254}$ of Merck 5554 .

\section{Plant materials}

The fruits of Johannesteijsmannia altifrons were collected at Pelagat Forest Reserve, Besut, Terengganu in February 2015. A voucher specimen (UKMB 40309) was deposited at the Herbarium of Universiti Kebangsaan Malaysia, Bangi (UKMB).

\section{Extraction and isolation}

The air-dried, fruits of Johannesteijsmannia altifrons (786 g) were extracted for 3 days in methanol at room temperature, followed by filtration to give methanol solution. They were then extracted with $n$-hexane three times, combined and rotary evaporated to afford $4.42 \mathrm{~g}(0.56 \%)$ of greenish brown fruit $n$-hexane extract. The extract was fractionated by VLC, eluted with increasing polarity of $n$-hexane-ethyl acetate to collect the less polar and more polar fractions. The fractions were combined based on their silica gel TLC profiles. The VLC gave 16 fractions $\left(F_{1}-F_{16}\right)$. Since fractions $F_{4}$ to $F_{7}$ have similar components, they were combined and further fractionated using $R C$ to produce four combined fractions $\left(\mathrm{F}_{41}-\mathrm{F}_{44}\right)$. The third fraction $\left(\mathrm{F}_{43}\right)$ contained $\beta$-sitosterol $(32 \mathrm{mg})$. Then, fractions $\mathrm{F}_{9}-\mathrm{F}_{12}$ were combined and purified by $\mathrm{RC}$ to yield 7 combined fractions $\left(\mathrm{F}_{91}-\mathrm{F}_{97}\right)$; fractions $\mathrm{F}_{94}$ and $\mathrm{F}_{96}$ contained $\gamma$-taraxasterol $(25 \mathrm{mg})$ and stigmasterol $(0.55 \mathrm{~g})$, respectively.

\section{Bioassay}

The pure compounds were assayed for antibacterial activity by using two methods which are disc diffusion and minimum inhibitory concentration (MIC) as described by Mamman et al. [7], Mukhtar and Ghori [8], and Yap et al. [9] with some modification, against nine bacteria; Staphylococcus aureus, Methicillin-resistant Staphylococcus aureus (MRSA), Bacillus subtilis, Bacillus thruriengiensis, Escherichia coli, Salmonella thyphimurium, Serratia marcescens, Vibrio fluvialis and Vibrio cholera. The pure compounds were prepared at $30 \mu \mathrm{g} / \mathrm{mL}$ in DMSO.

\section{Disc diffusion}

Disc diffusion method for antibacterial testing was carried out to determine antibacterial activity of the pure compounds. The nine bacteria were spread on the Mueller-Hinton agar surface by using a sterile swab and the plates were dried for 15 minutes. Then, $100 \mu \mathrm{L}$ of each dilution of the pure compounds was impregnated into sterile, blank disc of $6 \mathrm{~mm}$ in diameter and placed on the Mueller-Hinton agar surface. The positive control used was chloramphenicol $30 \mu \mathrm{g} / \mathrm{disc}$ which is a standard commercial antibiotic. The negative control used was DMSO $(100 \%)$. The plates were then incubated at $37^{\circ} \mathrm{C}$ for 24 hours. After the incubation, the plates were examined for inhibition zone and the results were recorded. The diameter of inhibition zones were measured in millimeter $(\mathrm{mm})$.The test was repeated three times to ensure reliability. 


\section{Minimum inhibition concentration}

Minimum Inhibition Concentration (MIC) was carried out to determine the lowest concentration of the compounds that could inhibit the visible growth of tested bacteria by using 96 microwell plate. An amount $100 \mu \mathrm{L}$ of pure compounds undergo dilutions from 30 to $0.117 \mu \mathrm{g} / \mathrm{mL}$. $50 \mu \mathrm{L}$ of nine bacteria were added into wells containing compounds. The 96 microwell plate was incubated at $37{ }^{\circ} \mathrm{C}$ for 24 hours. The positive and negative controls used were $100 \mu \mathrm{L}$ of respective chloramphenicol antibiotic and DMSO. Then, $50 \mu \mathrm{L}$ of 3-[4,5-dimethylthiazol-2-yl]-2,5diphenyltetrazolium bromide (MTT) was added to each single well and the plate was incubated at $37{ }^{\circ} \mathrm{C}$ for 2 hour. The colour development was observed and the results were recorded. The test was repeated three times to ensure reliability.

\section{Results and Discussion}

The ESI-MS gave molecular ion at $[\mathrm{M}+\mathrm{Na}]^{+} \mathrm{m} / \mathrm{z} 437.3381$ which $\beta$-Sitosterol appeared as colourless needles. The ESI-MS gave molecular ion at $[\mathrm{M}+\mathrm{Na}]^{+} \mathrm{m} / \mathrm{z} 437.3381$ which corresponded to the molecular formula $\mathrm{C}_{29} \mathrm{H}_{50} \mathrm{O}$ $(414.3862+22.9898=437.3759 ; \Delta 0.40513)$. The IR spectrum showed absorption peaks at $3385 \mathrm{~cm}^{-1}$ which is characteristic of O-H stretching, peaks at 2936 and $2868 \mathrm{~cm}^{-1}$ due to aliphatic or $\mathrm{C}-\mathrm{H}$ stretching $\left(\mathrm{CH}_{3}\right)$. Other absorption frequencies include peak at $1708 \mathrm{~cm}^{-1}$ due to absorption of $\mathrm{C}=\mathrm{C}$ stretching. The ${ }^{1} \mathrm{H}$ NMR spectrum of $\beta$-sitosterol showed a multiplet signal at $\delta_{\mathrm{H}} 3.53(\mathrm{H}-3)$, indicates the presence of a hydroxyl methine proton. The occurrence of a highly-deshielded signal at $\delta_{\mathrm{H}} 5.36(\mathrm{H}-6)$ indicates the presence of a vinylic proton. On the other hand, a singlet signal at $\delta_{\mathrm{H}} 1.02$ indicates a methyl group at $\mathrm{H}-29$. Two doublet signals at $\delta_{\mathrm{H}} 0.86$ and 0.91 are due to the two non-equivalent methyls at $\mathrm{H}-26$ and $\mathrm{H}-27$ of an isopropyl group. The ${ }^{13} \mathrm{C} N M R$ spectrum showed that $\beta$-sitosterol contains 29 different carbon atoms consisting of six methyls, 11 methylenes, nine methines, and three quaternary carbons. Signal of methine carbon at $\delta_{\mathrm{C}} 71.8 \mathrm{ppm}$ indicates a carbon attached to an oxygen atom which showed the existence of a hydroxyl group at C-3. Two highly deshielded signals at $\delta_{\mathrm{C}} 140.8$ and $121.7 \mathrm{ppm}$, which are assigned to $\mathrm{C}-5$ and $\mathrm{C}-6$ indicates there is one carbon double bond in the molecule. According to the available data as well as comparison with the literature [10], the compound is confirmed to be $\beta$-sitosterol.

$\gamma$-Taraxasterol was obtained as colourless needle crystal. The ESI-MS showed a molecular ion peak at $[\mathrm{M}+\mathrm{Na}]^{+} \mathrm{m} /$ $\mathrm{z} 449.2842$ which corresponded to the molecular formula $\mathrm{C}_{30} \mathrm{H}_{50} \mathrm{O}(426.3862+22.9898=449.3759 ; \Delta 0.09176)$. The IR spectrum displayed a broad absorbance peak at $3385 \mathrm{~cm}^{-1}$ which characteristic of $\mathrm{O}-\mathrm{H}$ stretching. Absorptions at 2927 and $2871 \mathrm{~cm}^{-1}$ represent the Csp $p^{3}-\mathrm{H}$ stretching. The ${ }^{1} \mathrm{H}$ NMR spectrum showed signal of a proton at $\delta_{\mathrm{H}} 3.51(\mathrm{H}-3)$ is attached to the oxygen-binding carbon $(\mathrm{C}-3)$. This is deshielded proton which is hydroxyl methine proton. Seven singlet methyls at signals $\delta_{\mathrm{H}} 1.61(\mathrm{H}-23), 1.10(\mathrm{H}-24), 0.82(\mathrm{H}-25), 0.81(\mathrm{H}-26), 1.29(\mathrm{H}-27)$, $0.80(\mathrm{H}-28)$ and $1.05(\mathrm{H}-30)$ indicating that they are attached to quaternary carbons and bound directly to the ring system. There is only one highly deshielded proton at $\delta_{\mathrm{H}} 5.37(\mathrm{H}-21)$ indicating the olefinic proton that attaches to a double bond carbon $(\mathrm{C}-21)$. The ${ }^{13} \mathrm{C}$ NMR spectrum showed $\gamma$-taraxasterol is formed by 30 carbon atoms consisting of eight methyls, nine methylenes, seven methines, and six quarternary carbons. A methine carbon at $\delta_{\mathrm{C}} 80.7$ indicates a carbon attached to an oxygen atom which showed the existence of a hydroxyl group at C-3. There are two highly deshielded olefinic carbon signals at $\delta_{\mathrm{C}} 141.0(\mathrm{C}-20)$ and 121.7 (C-21) suggests that there is one double bond contained in the molecule. Through comparison of the observed data with literature [11], the compound is identified as $\gamma$-taraxasterol.

Stigmasterol was isolated as colourless needles. The ESI-MS gave molecular ion at $[\mathrm{M}+\mathrm{Na}]^{+} \mathrm{m} / \mathrm{z} 435.3279$ which corresponded to the molecular formula $\mathrm{C}_{29} \mathrm{H}_{48} \mathrm{O}(412.3705+22.9898=435.3603 ; \Delta 0.0324)$. The IR spectrum displayed stretching band for $\mathrm{O}-\mathrm{H}$ at $3354 \mathrm{~cm}^{-1}$. Peaks at 2934 and $2866 \mathrm{~cm}^{-1}$ indicate the presence of aliphatic or $\mathrm{C}-\mathrm{H}$ stretching $\left(\mathrm{CH}_{3}\right)$. A band at $1667 \mathrm{~cm}^{-1}$ appears due to the existence of olefinic group in this compound. The ${ }^{1} \mathrm{H}$ NMR spectrum displayed signals for six methyls. Two singlet methyls at signals $\delta_{\mathrm{H}} 0.69(\mathrm{H}-18)$ and $1.02(\mathrm{H}-19)$ indicating that they are bound directly to the ring system. Three doublet methyls at $\delta_{\mathrm{H}} 0.93(\mathrm{H}-21), 0.84(\mathrm{H}-26)$ and $0.7(\mathrm{H}-27)$, and one triplet methyl at $\delta_{\mathrm{H}} 0.83(\mathrm{H}-29)$ are located at the side chain outside the rings of the main skeleton. Hydroxyl methine proton appeared at $\delta_{\mathrm{H}} 3.54$ (H-3) which attached to the oxygen-binding carbon (C-3). Three highly-deshielded protons presence at $\delta_{\mathrm{H}} 5.36,5.03$, and 5.09 due to the presence of two pairs of double bond which assigned at $\mathrm{H}-6, \mathrm{H}-22$ and $\mathrm{H}-23$. The ${ }^{13} \mathrm{C}$ NMR spectrum showed stigmasterol contained 29 carbon atoms consisting of six methyls, nine methylenes, 11 methines, and three quaternary carbons. Signal at $\delta_{\mathrm{C}} 71.8$ indicates a 

AND ANTIBACTERIAL ACTIVITY

methine carbon attached to an oxygen atom which showed the existence of a hydroxyl group at C-3. There are four olefinic carbon signals that appear downfield and highly deshielded at $\delta_{\mathrm{C}} 140.8(\mathrm{C}-5), 121.7(\mathrm{C}-6), 138.3(\mathrm{C}-22)$ and 129.3 (C-23) suggests that there are two double bonds in the molecule. Based on the discussion above and data comparison with literature [10], the compound is identified as stigmasterol. The spectra of $\beta$-sitosterol, $\gamma$-taraxasterol and stigmasterol are shown in Figures 1, 2 and 3, respectively.

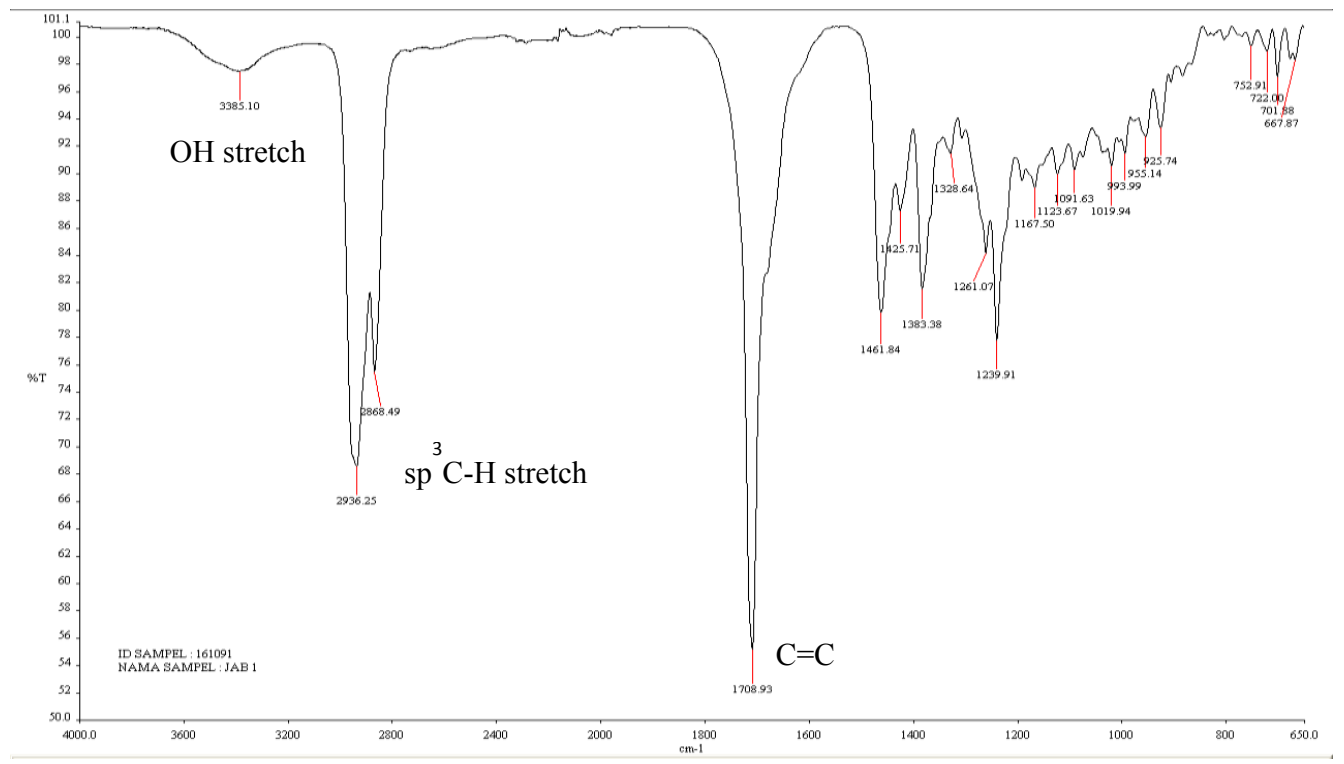

Figure 1. The infra-red spectrum of $\beta$-sitosterol

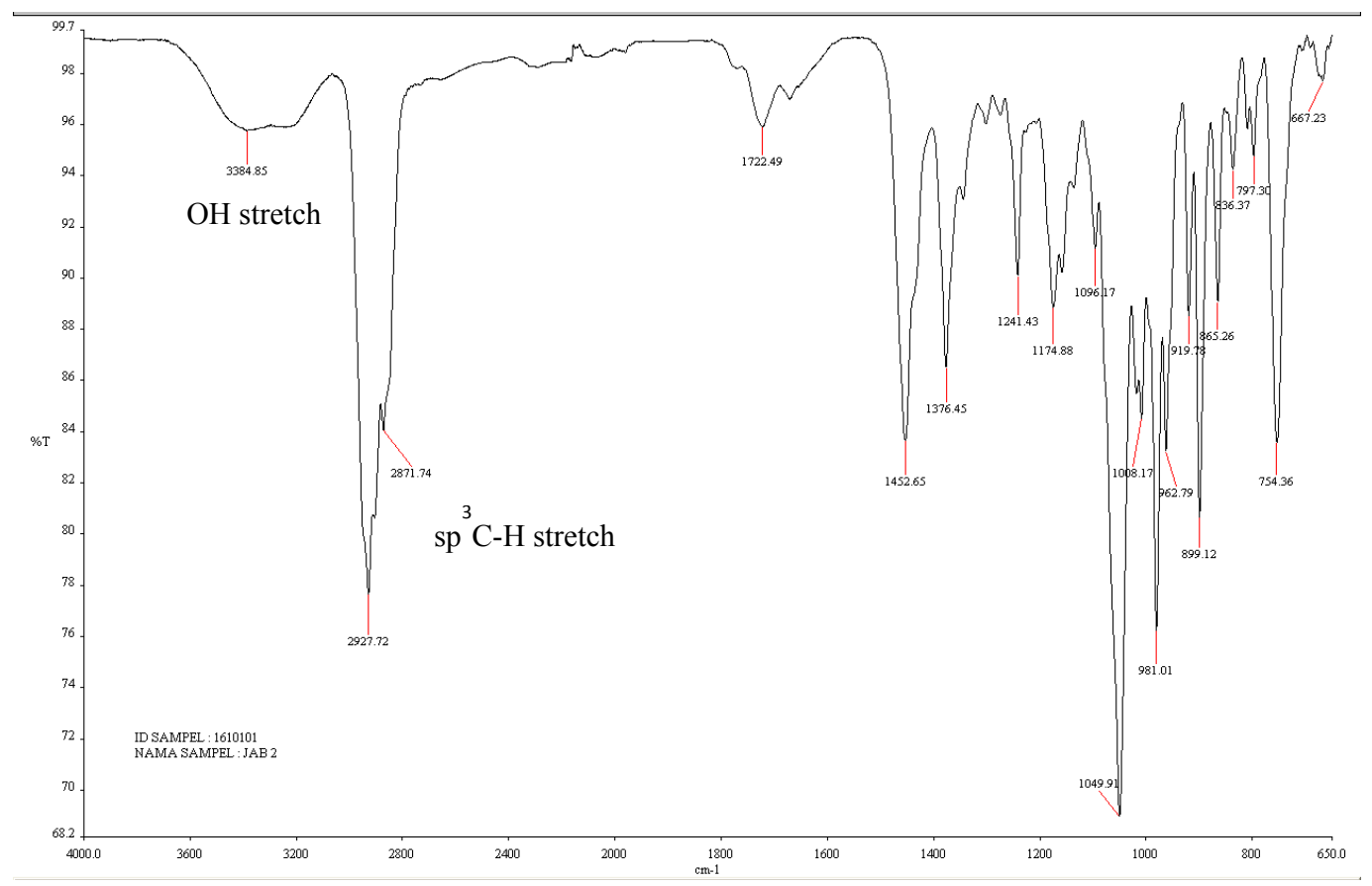

Figure 2. The infra-red spectrum of $\gamma$-taraxasterol 


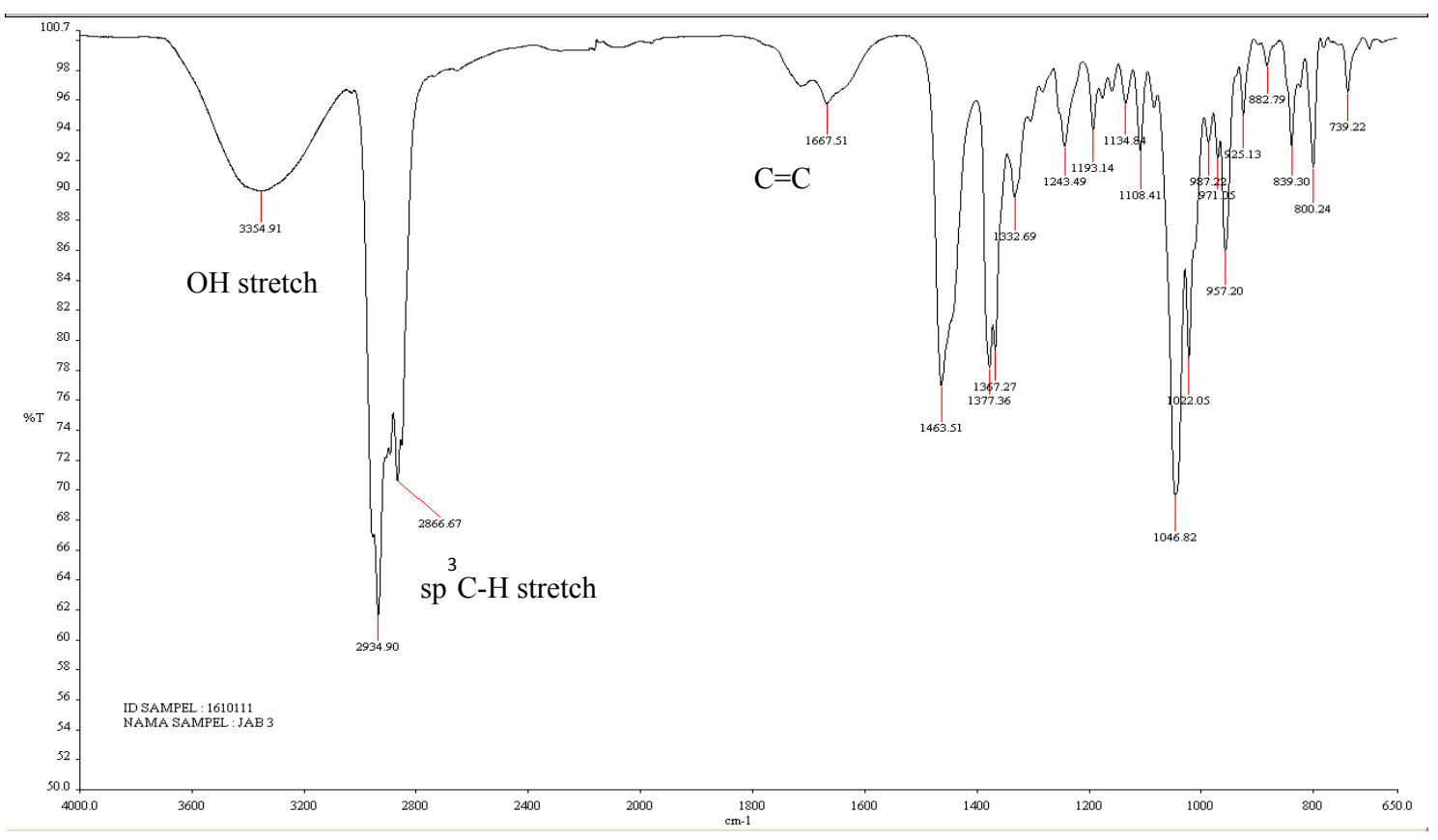

Figure 3. The infra-red spectrum of stigmasterol

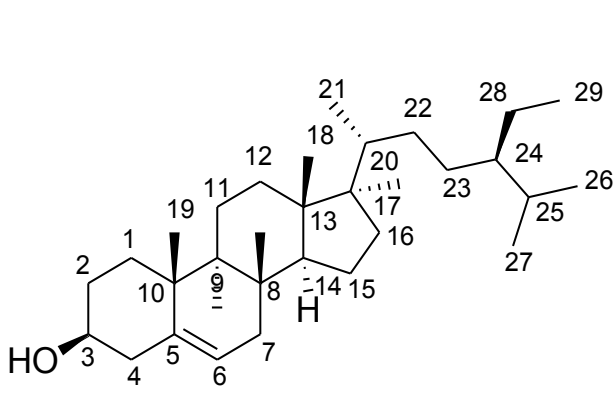

$\beta$-Sitosterol

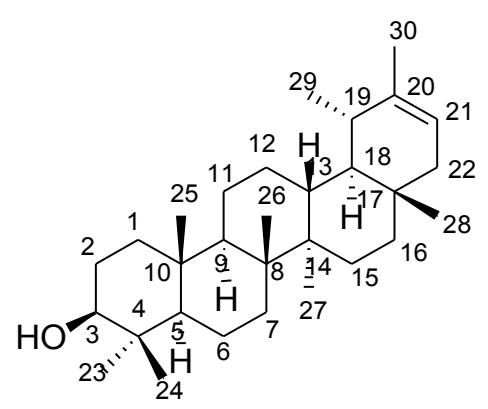

$\gamma$-Taraxasterol

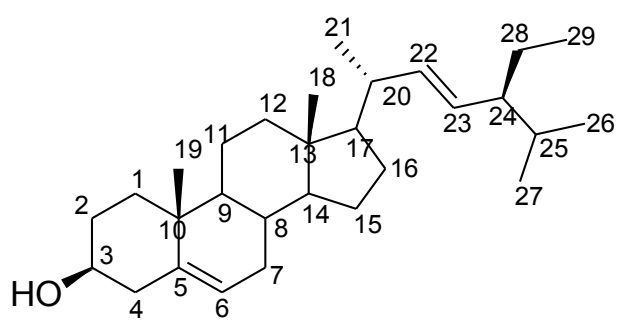

Stigmasterol

Figure 4. Structures of the pure compounds 


\section{Antibacterial activity}

The pure compounds isolated from the fruits of Johannesteijsmannia altifrons were tested for antibacterial activity. In disc diffusion method, $\beta$-sitosterol showed low inhibition which is $7.0 \pm 0.00 \mathrm{~mm}$ against Vibrio fluvialis, MRSA and Bacillus subtilis whereas $\gamma$-taraxasterol and stigmasterol exhibited moderate activities against Escherichia coli, Serratia marcescens, MRSA and Bacillus subtilis. Based on the results, it was observed that $\beta$-sitosterol has inhibition against one gram negative bacteria and two gram positive bacteria. This may probably due to the morphological differences between gram negative and gram positive bacteria in terms of their cell wall composition. The gram positive bacteria only have an outer peptidoglycan which is not effective permeability barrier compared to gram negative bacteria that have both outer membrane and peptidoglycan. This makes the gram negative bacteria cell wall impermeable to most of the drugs [12]. For stigmasterol, the inhibition occurs at low level (1+) against Staphylococcus aureus, Bacillus subtilis and Escherichia coli which is similar as reported by Singh dan Ghanapriya [5]. Besides, $\gamma$-taraxasterol showed moderate (2+) inhibition against Serratia marcescens and Bacillus subtilis. Kanamysin and vancomysin used as positive controls and the results showed all compounds have lower inhibitory activity against all tested bacteria compared to the antibiotics. DMSO as negative control did not show any antibacterial activity against tested bacteria. The inhibitory zone values for all compounds are shown in Table 1 .

Table 1. Antibacterial activity of the pure compounds in disc diffusion method

\begin{tabular}{lcccc}
\hline \multirow{2}{*}{ Pure Compounds } & $\boldsymbol{\beta}$-Sitosterol & $\boldsymbol{\gamma}$-Taraxasterol & Stigmasterol & $\begin{array}{c}\text { Kanamysin (K)* } \\
\text { Vancomysin (V) }\end{array}$ \\
\cline { 2 - 5 } & \multicolumn{4}{c}{ Inhibitory Zone (mm) } \\
\hline Escherichia coli $^{*}$ & - & $7.0 \pm 0.53$ & $7.0 \pm 0.00$ & $20 \pm 1.00(\mathrm{~K})$ \\
Vibrio fluvialis $^{*}$ & $7.0 \pm 0.00$ & $7.0 \pm 0.00$ & $7.0 \pm 0.00$ & $35 \pm 1.04(\mathrm{~K})$ \\
Salmonella thyphimurium $^{*}$ & - & $7.0 \pm 0.00$ & $7.0 \pm 0.00$ & $26 \pm 0.00(\mathrm{~K})$ \\
Vibrio cholera $^{*}$ & - & - & - & $10 \pm 0.00(\mathrm{~K})$ \\
Serratia marcescens $^{*}$ & - & $11.0 \pm 0.00$ & $11.0 \pm 0.00$ & $23 \pm 1.52(\mathrm{~K})$ \\
Methicillin-resistant Staphylococcus $^{*}$ & $7.0 \pm 0.00$ & $7.0 \pm 0.00$ & $8.0 \pm 0.5$ & $20 \pm 0.00(\mathrm{~V})$ \\
aureus $\left(\right.$ MRSA) $^{* *}$ & & & & \\
Bacillus thruriengiensis $^{* *}$ & - & - & - & $22 \pm 0.00(\mathrm{~V})$ \\
Bacillus subtilis $^{* *}$ & $7.0 \pm 0.00$ & $10.0 \pm 0.5$ & $7.0 \pm 0.00$ & $28 \pm 0.00(\mathrm{~V})$ \\
Staphylococcus aureus $^{* *}$ & - & $7.0 \pm 0.53$ & $7.0 \pm 0.00$ & $25 \pm 0.00(\mathrm{~V})$ \\
\hline
\end{tabular}

Mean measurement: SD $(\mathrm{n}=3),{ }^{*}$ Gram negative ${ }^{* *}$ Gram positive

In minimum inhibition concentration (MIC) method, all compounds gave value of $7.5 \mu \mathrm{g} / \mathrm{mL}$ against Staphylococcus aureus, Escherichia coli, Vibrio cholera, Serratia marcescens, Bacillus thruriengiensis and Bacillus subtilis whereas previous report showed both $\beta$-sitosterol and stigmasterol have higher MIC value of $16.5 \mu \mathrm{g} / \mathrm{mL}$ and no inhibition against Escherichia coli and Bacillus subtilis. No explanation can be given on the difference. First report on antibacterial activity of $\gamma$-taraxasterol provides new knowledge for the compound. The MIC values are shown in Table 2. 
Table 2. Antibacterial activity of the pure compounds in minimum inhibitory concentration (MIC) method

\begin{tabular}{lccc}
\hline \multirow{2}{*}{ Pure compounds } & $\boldsymbol{\beta}$-Sitosterol & $\boldsymbol{\gamma}$-Taraxasterol & Stigmasterol \\
\cline { 2 - 4 } & \multicolumn{3}{c}{$\boldsymbol{M I C}(\boldsymbol{\mu g} / \mathbf{m L})$} \\
\hline Escherichia coli & 7.5 & 7.5 & 7.5 \\
Vibrio fluvialis & 30 & 30 & 30 \\
Salmonella thyphimurium & 15 & 15 & 15 \\
Vibrio cholera & 7.5 & 7.5 & 7.5 \\
Serratia marcescens & 7.5 & 7.5 & 7.5 \\
Methicillin-resistant Staphylococcus aureus (MRSA) & 15 & 15 & 30 \\
Bacillus thruriengiensis & 7.5 & 7.5 & 7.5 \\
Bacillus subtilis & 7.5 & 7.5 & 7.5 \\
Staphylococcus aureus & 7.5 & 7.5 & 7.5 \\
\hline
\end{tabular}

\section{Conclusion}

The investigation on the chemical constituents from fruits of Johannesteijsmannia altifrons resulted in the isolation of three known compounds which are $\beta$-sitosterol, $\gamma$-taraxasterol and stigmasterol. In disc diffusion method, the isolated compounds showed no inhibition against Vibrio cholera and Bacillus thruriengiensis, and weak or moderate activities against other seven bacteria. In MIC method, the lowest and highest MIC values were at respective 7.5 and $30 \mu \mathrm{g} / \mathrm{mL}$. All the compounds have been reported for the first time from this plant.

\section{Acknowledgment}

Authors would like to thank the Ministry of Education, Malaysia and Universiti Kebangsaan Malaysia (UKM) for the financial support under DLP-2013-018 grant and "Program Pelajar Cemerlang (PPC)" scholarship under Public Service Department, Malaysia. Special thanks to School of Chemical Sciences and Food Technology, Faculty of Science and Technology, UKM and Centre for Research and Innovation Management (CRIM) UKM for technical support on NMR, LC-MSToF, UV and FTIR instrumentation.

\section{References}

1. Dransfield, J. (1972). The genus Johannesteijsmannia H. E. Moore Jr. The Gardens Bulletin Singapore, 26: 6383.

2. Muhaisen, H. (2002). Flavonoids from the base leaves of Caryota urens (Palmae). American Scientific Publishers, 6(11): 1225 - 1229.

3. Dyana, J. P. and Kanchana, G. (2012). Preliminary phytochemical screening of Cocos nucifera L. flowers. International Journal of Current Pharmaceutical Research, 4(3): 3 - 4.

4. Benmehdi, H., Hasnaoui, O., Benali, O. and Salhi, F. (2012). Phytochemical investigation of leaves and fruits extracts of Chamaerops humilis L. Journal of Material and Environmental Science, 3(2): 320 - 237.

5. Singh, S. and Ghanapriya, N. (2014). Chemical constituents and antibacterial activity of Phaleria macrocarpa. International Journal of Pharmaceutical Sciences and Research, 5(8): 3157 - 3162.

6. Manríquez-Torres, J. J., Zúñiga-estrada, A., González-ledesma, M. and Torres-valencia, J. M. (2007). The antibacterial metabolites and proacacipetalin from Acacia cochliacantha. Journal of the Mexican Chemical Society, 51(4): $228-231$.

7. Mamman, P. H., Mshelia, W. P., Susbatrus, S. C. and Sambo, K. W. (1989). Antibacterial effects of crude extract of Azadirachta indica against Escherichia coli, Salmonella 142 spp and Staphylococcus aureus. International Journal of Medicine and Medical Sciences, 5(1): 14 - 18.

8. Mukhtar, S. and Ghori, I. (2012). Antibacterial activity of aqueous and ethanolic extracts of garlic, cinnamon and turmeric against Escherichia coli ATCC 25922 and Bacillus subtilis DSM 3256. International Journal of Applied Biology and Pharmaceutical Technology, 3(2): 131 - 136. 
9. Yap, P. S. X., Chong Y. T. E., Wong, Y. Y., Lim, X. Y., Ang J. H., Goh, H. S. L., Lai, M. X. S, Mai, C. W., Buru, S. A., Pichika, M. R. and Lim, S. H. E. (2013). Antibacterial and antifungal testing of the different extracts of Dillenia obovata (blume) Hoogl. World Journal of Pharmacy and Pharmaceutical Sciences, 2(5): $3946-3962$.

10. Chaturvedula, V. S. P. and Prakash, I. (2012). Isolation of Stigmasterol and $\beta$-Sitosterol from the dichloromethane extract of Rubus suavissimus. International Current Pharmaceutical Journal, 1(9): 239 - 242.

11. Yekta, M. M., Hamid, S. and Alavi, R. (2008). New triterpenoids from Peucedanum ruthenicum. Iranian Journal of Pharmaceutical Sciences, 4(4): 289 - 294.

12. Ghansar, N. H., Bhopale, S. U. and Prabhune, V. S. (2012). In vitro studies of antimicrobial properties of extracts from Unani medicinal plants. International Journal of Pharmaceutical Bio Sciences, 3(1): 240 - 249. 